\title{
CHLOROGENIC ACID CONTENT AND ANTIOXIDANT PROPERTIES OF POTATO TUBERS AS RELATED TO NITROGEN FERTILISATION
}

\author{
A. LUGASI ${ }^{a}$, D. P. F. ALMEIDA ${ }^{\text {b }}$, and E. DWORSCHÁK $^{\mathrm{a}}$ \\ a National Institute of Food Hygiene and Nutrition, Gyáli út 3/a, Budapest, Hungary. H-1097 \\ ${ }^{\mathrm{b}}$ University of Trás-os-Montes e Alto Douro, Crop Science Department, Apartado 202, \\ 5001 Vila Real Codex. Portugal
}

(Received: 10 August 1998, accepted: 14 December 1998)

\begin{abstract}
The chlorogenic acid and the total polyphenol content were analysed in two different potato varieties (Kennebec, Agria) grown under five different nitrogen fertiliser rates $(0,75,150$, $225,300 \mathrm{~kg} \mathrm{ha}^{-1}$ ). Chlorogenic acid content ranged between $6.0-22.3 \mathrm{mg} \mathrm{kg}^{-1}$ fresh weight and was not influenced by fertiliser levels. The chlorogenic acid in potato tubers accounted for almost $90 \%$ of the total polyphenols. Free radical scavenging and antioxidant acitivities of the tubers were also analysed. Ethanolic extracts of the tubers showed marked hydrogen-donating activity in the experiment using 1,1-diphenyl-2-picrylhydrazyl (DPPH), they had reducing power as measured by the $\mathrm{Fe}(\mathrm{III}) \rightarrow \mathrm{Fe}(\mathrm{II})$ reaction, but did not exhibit $\mathrm{H}_{2} \mathrm{O}_{2}$ scavenging activity assessed with a chemiluminescence method. Potato extracts showed significant, although weak $\mathrm{Cu}(\mathrm{II})$ chelating activity and inhibited the autoxidation of linoleic acid as measured by the thiocyanate method. Chlorogenic acid containing extract of potato, can act as primary and secondary antioxidant in prevention of oxidative stress. The strong correlation between the antioxidant activity and the level of total pholyphenols suggests that the phenolic compounds are important antioxidant components of whole potato tubers. Variety had minimal, while nitrogen fertiliser rate had no effects on the levels of the studied characteristics.
\end{abstract}

Keywords: antioxidant, free radical scavenger, chlorogenic acid, chemiluminescence, potato, nitrogen fertiliser

Foods of plant origin, including potato, contain several secondary metabolites: phenolic compounds (chlorogenic acid, caffeic acid), glycoalkaloids ( $\alpha$-chaconine, $\alpha$ solanine), protease inhibitors, and phytoalexins which protect the plant tissues against pathogens and pests (DAO \& FRIEDMAN, 1992). Potato is considered a good source of antioxidants such as ascorbic acid, $\alpha$-tocopherol and polyphenolic compounds, which act synergistically to inhibit the free radical-induced tissue damage (BYERS \& PERRY, 1992). 
Chemistry, biochemistry, and the dietary role of potato polyphenols were recently reviewed by FriEDMAN (1997). Chlorogenic acid (5-O-caffeoyl-quinic acid) constitutes about $90 \%$ of the total polyphenol content of potatoes (DAO \& FRIEDMAN, 1992). This compound may be responsible for the "after-cooking blackening or darkening" of boiled and steamed potatoes. The blackening appears to be caused by the formation of a ferrous ion - chlorogenic acid complex. Following exposure to oxygen in the air, the colourless ferrous complex is oxidised to a dark ferric complex (HUNGHES et al., 1962). Chlorogenic acid also participates in enzymatic browning which can lead to nutritional damage (Molnar-Perl \& Friedman, 1990). Chlorogenic acid is oxidised by polyphenol oxidase to a highly reactive o-quinone intermediate which could interact with different amino acids in nucleophil addition and in polymerisation reactions. These reactions destroy essential amino acids, decrease the nutritional quality and may also result in the formation of toxic compounds (FrIEDMAN, 1992, 1996).

Recently, several studies have been focused on the antioxidant activity of phenolic compounds in potato. ONYENEHO and HETTIARACHCHY (1993) evaluated the effectiveness of freeze-dried extracts from the peel of potato varieties for their ability to prevent soybean-oil autoxidation. Chlorogenic and protocatechuic acids were the main antioxidants in the extracts. RODRIGUEZ DE SOTILlo and co-workers (1994a, 1994b) confirmed the strong antioxidant activity of freeze-dried extract of potato peel waste in sunflower oil. These results have suggested that potato peel has possible preventive effects against oxidative rancidity of food products. AL-SAIKHAN and co-workers (1995) found that phenolic content and antioxidant activity of four potato cultivars were genotype-dependent. VINSON and co-workers (1995) showed that chlorogenic acid and other polyphenols exhibit strong in vitro antioxidant activity in the oxidation process of lipoproteins. In vivo oxidation of low-density lipoproteins appears to be a major cause of coronary heart disease (CDH). It is thus possible that foods containing chlorogenic acid and other polyphenols may decrease the incidence of $\mathrm{CDH}$.

FELICE and co-workers (1976) observed that caffeic acid and chlorogenic acid were effective scavengers of peroxyl radicals and more reactive than the corresponding quinones which are formed by oxidation of the phenolic acids mentioned above. On the other hand, quinones are better metal-chelating antioxidative agents than the phenolic acids. Both effects are involved in the antioxidant behaviour of polyphenolic compounds. Chlorogenic acid and other polyphenols are reported as inhibitors of cancer development due to their ability to scavenge and trap potentially DNAdamaging electrophiles and free radicals, to inhibit enzymes that activate precarcinogens, and to induce carcinogen-detoxifying enzymes (STEVENS et al., 1995). Chlorogenic acid suppresses the elevation of serum cholesterol level by alcoholism, stimulates bile acid secretion, inhibits lipid peroxidation in liver mitochondria and 
microsomes, and shows protective effects on paraquat-induced oxidative stress in rats (LAZAROV \& Werman, 1996; TSUCHIYA et al., 1996).

DAO and FRIEDMAN (1992) called attention to the fact that food processing technologies such as heating induce a decrease in chlorogenic acid content of potatoes. This compound can be partially or even completely destroyed by the usual cooking conditions. This decrease appeared to depend on the nature of the heat used, microwaves seemed to be the least destructive, boiling and oven-baking intermediate and the most destructive, respectively. Commercial potato chips and mashed potato flakes did not contain chlorogenic acid (DAO \& FRIEDMAN, 1992), thus querying the potential health benefits of the potato phenolics.

The objectives of our work were to investigate [1] the chlorogenic acid and the total polyphenol content of two potato cultivars grown under five different fertiliser rates, [2] the free radical scavenging and antioxidant activity of the potato and [3] to establish the relationships among the characteristics mentioned above.

\section{Materials and methods}

\subsection{Chemicals}

1,1-Diphenyl-2-picrylhydrazyl (DPPH), tetramethyl murexide (TMM), chlorogenic acid, luminol, microperoxidase, and linoleic acid were obtained from Sigma Chemical (Co(MO, USA). Absolute ethanol and hexamine were purchased from Merck (Germany). All other chemicals and reagents were of analytical grade from Reanal (Hungary).

\subsection{Plant material}

Potato (Solanum tuberosum L. cvs. Agria and Kennebec) were grown in the spring of 1995 in Vila Real, Portugal. Five nitrogen levels - 0, 75, 150, 225 and $300 \mathrm{~kg} \mathrm{~N} \mathrm{ha}^{-1}$ - were combined with both cultivars in completely randomised block design with four replications. All the nitrogen fertilisers were applied at planting in the form of $\mathrm{NH}_{4} \mathrm{NO}_{3}$. At harvest, samples of 5 tubers including peel with diameter between $35-55 \mathrm{~mm}$, showing no signs of pests or diseases, were collected, freeze-dried, and kept in a sealed plastic bag until analysed.

\subsection{Preparation of the potato extract}

The freeze-dried potato powders were first defatted with $n$-hexane. A portion of defatted powder $(500 \mathrm{mg})$ was then refluxed for $6 \mathrm{~h}$ with $20 \mathrm{ml}$ of ethanol in Soxhlet extractor (FriEDMAN et al., 1989). The refluxed sample was then filtered 
through Whatman 4 filter paper and the filtrate adjusted to a volume of $20 \mathrm{ml}$ with ethanol. The extracts were stored in a refrigerator at $4{ }^{\circ} \mathrm{C}$ until analysed.

\subsection{Chlorogenic acid determination}

For the chlorogenic acid determination (and for the other spectrophotometric measurements used in this study) a Perkin-Elmer Lambda3 UV-VIS spectrophotometer was used. The UV spectrum of the potato extracts was determined at 250-400 nm according to DAO and FRIEDMAN (1992). The concentration was calculated from the absorption maximum at $325 \mathrm{~nm}$ for a standard of chlorogenic acid. The molar extinction coefficient of chlorogenic acid was determined as $18130 \mathrm{M}^{-1} \mathrm{~cm}^{-1}$.

\subsection{Total polyphenol determination}

The total polyphenol content present in the ethanolic extract of freeze-dried potato powder was determined spectrophotometrically using Folin-Denis reagent (A.O.A.C. 1990). The ethanolic extract of potatoes $(1 \mathrm{ml})$ was diluted with distilled water to $7 \mathrm{ml}$. Folin-Denis reagent $(0.5 \mathrm{ml})$ was added, and the content of the tube was mixed thoroughly. After $3 \mathrm{~min}, 1 \mathrm{ml}$ of saturated $\mathrm{Na}_{2} \mathrm{CO}_{3}$ was added and the final volume adjusted to $10 \mathrm{ml}$ with distilled water. The mixture was allowed to stand for 30 min at room temperature. The absorbance was determined at $760 \mathrm{~nm}$ using tannic acid as standard.

\subsection{Hydrogen-donating ability}

Hydrogen-donating ability of potato extracts was determined in the presence of 1,1-diphenyl-2-picrylhydrazyl (DPPH) radical as described by BLOIS (1958) and modified by HATANO and co-workers (1988). Ethanolic extract of potato $(1 \mathrm{ml})$ and a portion ethanol $(3 \mathrm{ml})$ were added to a methanolic solution of DPPH $(1 \mathrm{mM}, 1 \mathrm{ml})$. The mixture was shaken and left to stand at room temperature for $30 \mathrm{~min}$. The absorbance of the resulting solution was measured spectrophotometrically at $517 \mathrm{~nm}$. Hydrogendonating ability of the extracts was given by the inhibition of the colour development expressed as percentage of the control, which contained ethanol instead of the potato extract.

\subsection{Reducing power}

The reducing power of the potato extracts was determined according to the method of OYAIZU (1986). Ethanolic extract $(1 \mathrm{ml})$ was mixed with phosphate buffer (2.5 ml, 0.2 M, pH 6.6) and $1 \%$ potassium ferricyanide $/ \mathrm{K}_{3} \mathrm{Fe}(\mathrm{CN})_{6} /(2.5 \mathrm{ml})$; the mixture was incubated at $50{ }^{\circ} \mathrm{C}$ for $20 \mathrm{~min}$. Trichloracetic acid $(2.5 \mathrm{ml}, 10 \%)$ was 
added to the mixture, which was then centrifuged at $1.500 \mathrm{~g}$ for $10 \mathrm{~min}$. The upper layer of solution $(2.5 \mathrm{ml})$ was mixed with distilled water $(2.5 \mathrm{ml})$ and freshly prepared $\mathrm{FeCl}_{3}$ solution $(0.5 \mathrm{ml}, 0.1 \%)$. The absorbance was measured at $700 \mathrm{~nm}$. Increased absorbance of the reaction mixture indicates elevated reducing power.

\subsection{Copper(II)-chelating activity}

The chelating activity of potato extracts on copper(II)-ions was measured according to SHIMADA and co-workers (1992), with a minor modification. An aliquot of potato extract $(1 \mathrm{ml})$ was added to hexamine buffer $(1.0 \mathrm{ml}, 10 \mathrm{mM}, \mathrm{pH}=5.0)$ containing $\mathrm{KCl}(10 \mathrm{mM})$ and $\mathrm{CuSO}_{4} \cdot 5 \mathrm{H}_{2} \mathrm{O}(3 \mathrm{mM})$. The reaction mixture was shaken well and after 2 min tetramethylmurexide (TMM) $(0.1 \mathrm{ml}, 1 \mathrm{mM})$ was added. Absorbances at 485 and $530 \mathrm{~nm}$ were measured. Copper(II)-ions in hexamine buffer show an absorption maximum at $485 \mathrm{~nm}$ in the presence of TMM. Strong chelating agents such as EDTA and polyphenols form new complex molecules with copper ions that give absorbance maximum at $530 \mathrm{~nm}$. The position of the absorption maximum depends on the concentration and the copper-binding ability of the compounds. Chelating activity was determined as the absorbance ratio at $485 \mathrm{vs} 530 \mathrm{~nm}$. Lower absorbance ratios indicate higher chelating activity compared to the control.

\subsection{Scavenging activity in $\mathrm{H}_{2} \mathrm{O}_{2} / \cdot \mathrm{OH}$-luminol system}

The scavenging activity of the potato extracts in $\mathrm{H}_{2} \mathrm{O}_{2} / \cdot \mathrm{OH}$-luminol system was measured with the use of a Berthold Lumat LB 9501 luminometer according to HEIDE and BÖGL (1986), and modified by BLÁZOVICS and co-workers (1992). Unstable free radicals formed from $\mathrm{H}_{2} \mathrm{O}_{2}$ in the presence of transitional metal ions via Fenton reaction decompose the luminol to inactive amino-phthalic acid while monochromatic light $(\lambda=425 \mathrm{~nm})$ is emitted. The reactions can be catalysed by hemin, or microperoxidase. We used microperoxidase in our experiments. The intensity of the chemiluminescence expressed as relative light unit (RLU) is reduced by free radical scavenged substances. The highest chemiluminescence intensity - the standard light is given by the $\mathrm{H}_{2} \mathrm{O}_{2} / \mathrm{OH}$-luminol system. The reaction mixture contained $0.3 \mathrm{ml}$ of $\mathrm{H}_{2} \mathrm{O}_{2}\left(10^{-4} \mathrm{M}\right), 0.05 \mathrm{ml}$ of luminol $\left(7 \cdot 10^{-7} \mathrm{M}\right), 0.3 \mathrm{ml}$ of microperoxidase $\left(10^{-7} \mathrm{M}\right)$ and $0.2 \mathrm{ml}$ of sample. Measurements were made over a $30 \mathrm{sec}$ period.

\subsection{Antioxidant activity}

The antioxidant activity of potato extracts was determined according to the thiocyanate method (MITSUDA et al., 1966) with a slight modification. An aliquot of potato extract $(0.5 \mathrm{ml})$ was added to $9.5 \mathrm{ml}$ linoleic acid emulsion $(500 \mathrm{mg}$ linoleic acid was dissolved in $40 \mathrm{ml}$ of absolute ethanol, mixed well and then $40 \mathrm{ml} \mathrm{pH=7.0}$ 
phosphate buffer was added and diluted to $100 \mathrm{ml}$ with distilled water.) The reaction mixture was stored for 7 days at $40{ }^{\circ} \mathrm{C}$. After the storage period $0.1 \mathrm{ml}$ portion of the reaction mixture was added to $9.7 \mathrm{ml}$ ethanol $\left(750 \mathrm{ml} \mathrm{l}^{-1}\right)$ and $0.1 \mathrm{ml}$ of thiocyanate solution (30\%). Three min later, the mixture was completed by the addition of a $\mathrm{FeSO}_{4}$ solution $(0.1 \mathrm{ml}, 0.02 \mathrm{M}$ in $3.5 \% \mathrm{HCl}$ solution). The absorbance was read at $500 \mathrm{~nm}$, and the antioxidant activity was expressed in percentage of the inhibition of the linoleic acid autooxidation compared to the control mixture.

\subsection{Statistical analysis}

The field experiment was designed as a randomised complete block with two factors (cultivar and fertiliser rate). The data were analysed by two-factor ANOVA and the means separated using the Fisher's least significant difference test.

\section{Results and discussion}

The chlorogenic acid concentrations of the tubers ranged from 12.9 to $14.5 \mathrm{mg}$

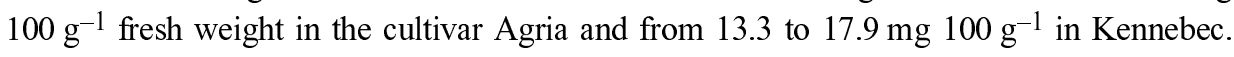
The $\mathrm{N}$ fertiliser rate had no effect on chlorogenic acid content (Table 1). Chlorogenic acid affects the taste and flavour of potatoes (MARTENS \& BAARDSETH, 1987), and is involved in the defence against insects and phytopathogens (SINDEN et al., 1988) and has strong antioxidant activity (PRATT, 1993). Chlorogenic acid has superoxide radical scavenging activity in a concentration-dependent manner (TSUCHIYA et al., 1996). This radical scavenging ability is stronger than that of $\beta$-carotene and synthetic butylhydroxyanisol but weaker than that of vitamin $\mathrm{E}$. The concentration of total polyphenols in the potato tubers varied between $14.0-16.6 \mathrm{mg} 100 \mathrm{~g}^{-1}$ f.w. in the cultivar Agria and $14.0-18.5 \mathrm{mg}$ $100 \mathrm{~g}^{-1}$ f.w. in Kennebec and was not affected by the $\mathrm{N}$ rate (Table 1). The levels of chlorogenic acid made up $88.9 \pm 10.3 \%$ of the total polyphenols in potato tubers, which are consistent with the values reported by DAO and FriedMAN (1992) and MONDY and GOSSELIN (1988).

The levels of chlorogenic acid and total phenolics reported here are similar to those previously published by AL-SAIKHAN and co-workers (1995), by DAO and FriedMAN $(1992,1996)$ and by KARIM and co-workers (1997), but lower than the results presented by THOMAS and JOSHI (1977). Differences may be attributed to genotypes and environmental conditions in which the potatoes were grown. AL-SAIKHAN and co-workers (1995) showed that the accumulation of phenolics is genotype-dependent. The levels of chlorogenic acid in seven potato varieties ranged from 9.7 to $18.7 \mathrm{mg} 100 \mathrm{~g}^{-1}$ fresh weight (DAO \& FRIEDMAN, 1992). 
Table 1

Concentration of chlorogenic acid and total phenols in tubers of potatoes grown with several nitrogen application rates

\begin{tabular}{|c|c|c|c|c|}
\hline \multirow[t]{2}{*}{$\begin{array}{c}\text { N rate } \\
\left(\mathrm{kg} \mathrm{ha}^{-1}\right)\end{array}$} & \multicolumn{2}{|c|}{$\begin{array}{l}\text { Chlorogenic acid } \\
\text { (mg } 100 \mathrm{~g}^{-1} \text { f.w.) }\end{array}$} & \multicolumn{2}{|c|}{$\begin{array}{l}\text { Total polyphenols } \\
\text { (mg } 100 \mathrm{~g}^{-1} \text { f.w.) }\end{array}$} \\
\hline & Agria & Kennebec & Agria & Kennebec \\
\hline 0 & $14.0 \pm 1.6 \mathrm{a}$ & $13.5 \pm 1.3 \mathrm{a}$ & $16.6 \pm 2.3 \mathrm{a}$ & $17.0 \pm 2.2 \mathrm{a}$ \\
\hline 75 & $13.3 \pm 1.0 \mathrm{a}$ & $14.6 \pm 1.0 \mathrm{a}$ & $15.8 \pm 1.1 \mathrm{a}$ & $16.5 \pm 2.1 \mathrm{a}$ \\
\hline 150 & $13.6 \pm 2.0 \mathrm{a}$ & $13.3 \pm 1.2 \mathrm{a}$ & $14.1 \pm 1.8 \mathrm{a}$ & $14.9 \pm 1.6 \mathrm{a}$ \\
\hline 225 & $14.2 \pm 1.9 \mathrm{a}$ & $17.5 \pm 1.7 \mathrm{a}$ & $16.0 \pm 2.0 \mathrm{a}$ & $19.5 \pm 2.2 \mathrm{a}$ \\
\hline 300 & $12.9 \pm 1.1 \mathrm{a}$ & $17.9 \pm 0.6 \mathrm{a}$ & $15.3 \pm 0.8 \mathrm{a}$ & $18.5 \pm 0.3 a$ \\
\hline Average & $13.6 \pm 0.6 \mathrm{a}$ & $15.4 \pm 0.7 \mathrm{a}$ & $15.5 \pm 0.7 \mathrm{a}$ & $17.3 \pm 0.8 \mathrm{a}$ \\
\hline
\end{tabular}

Values are means \pm SE of 4 replications. Mean separation by Fisher LSD test, $5 \%$ level. Mean separation by rows for the $\mathrm{N}$ levels and by columns for the averages over $\mathrm{N}$ levels

Different parts of the potato plant had much wider range of chlorogenic acid content than the tubers. The highest concentration was found in sprouts, followed by leaves, roots and finally the tubers, indicating that chlorogenic acid concentrations are also organ-dependent.

Ethanolic extracts of potato tubers had strong hydrogen donating ability in the presence of DPPH radical (Table 2). Hydrogen-donating ability is an index of the primary antioxidant activity of the tubers. Primary or chain-breaking antioxidants give hydrogen to free radicals, particularly the lipid hydroperoxide radicals which are the major propagator of the chain autoxidation of fats. This conversion leads to non-radical species, therefore inhibiting the propagation phase of lipid peroxidation. We found no correlation between hydrogen-donating activity and the concentration of chlorogenic acid and/or total polyphenols. H-donating activity was higher in the cultivar Kennebec.

All the samples exhibited strong reducing power (Table 2). Reducing power can be interpreted as an index of secondary antioxidant activity. Secondary or preventive antioxidants can reduce the rate of chain initiation in the lipid peroxidation process or can react with the products of lipid peroxidation. This conversion leads to more stable non-radical, non-deleterious products. A significant linear correlation was found between the reducing power and both the chlorogenic acid $(r=0.817 ; n=40)$ and the polyphenol content $(\mathrm{r}=0.859 ; \mathrm{n}=40)$ as shown in Figs $1 / \mathrm{a}$ and $1 / \mathrm{b}$. 
Table 2

Hydrogen-donating ability and reducing power of ethanolic extracts from tubers of potatoes grown with several nitrogen application rates

\begin{tabular}{|c|c|c|c|c|}
\hline \multirow[t]{2}{*}{$\begin{array}{c}\text { N rate } \\
\left(\mathrm{kg} \mathrm{ha}^{-1}\right)\end{array}$} & \multicolumn{2}{|c|}{$\begin{array}{l}\text { H-donating ability } \\
\text { (\% inhibition) }\end{array}$} & \multicolumn{2}{|c|}{$\begin{array}{l}\text { Reducing power } \\
\text { (Abs } 700 \mathrm{~nm})\end{array}$} \\
\hline & Agria & Kennebec & Agria & Kennebec \\
\hline 0 & $28.5 \pm 4.1 \mathrm{a}$ & $36.5 \pm 4.5 \mathrm{a}$ & $0.16 \pm 0.02 \mathrm{a}$ & $0.25 \pm 0.06 \mathrm{a}$ \\
\hline 75 & $33.0 \pm 0.9 \mathrm{a}$ & $39.0 \pm 8.2 \mathrm{a}$ & $0.16 \pm 0.01 \mathrm{a}$ & $0.23 \pm 0.03 \mathrm{a}$ \\
\hline 150 & $37.0 \pm 6.6 \mathrm{a}$ & $35.8 \pm 2.4 \mathrm{a}$ & $0.20 \pm 0.03 a$ & $0.20 \pm 0.02 \mathrm{a}$ \\
\hline 225 & $38.0 \pm 4.1 \mathrm{a}$ & $45.5 \pm 4.0 \mathrm{a}$ & $0.21 \pm 0.02 \mathrm{a}$ & $0.26 \pm 0.04 \mathrm{a}$ \\
\hline 300 & $36.3 \pm 3.9 \mathrm{a}$ & $53.3 \pm 3.1 \mathrm{a}$ & $0.21 \pm 0.03 a$ & $0.24 \pm 0.01 \mathrm{a}$ \\
\hline Average & $34.6 \pm 1.9 \mathrm{~b}$ & $42.0 \pm 2.5 \mathrm{a}$ & $0.19 \pm 0.01 \mathrm{a}$ & $0.24 \pm 0.02 \mathrm{a}$ \\
\hline
\end{tabular}

Values are means \pm SE of 4 replications. Mean separation by Fischer LSD test, $5 \%$ level. Mean separation by rows for the $\mathrm{N}$ levels and by columns for the averages over $\mathrm{N}$ levels

Although chelating agents are not antioxidants, they play a valuable role in stabilising fatty foods against rancidity. During the propagation phase of lipid peroxidation, decomposition of the lipid hydroperoxides catalysed by transition metal ions $\left(\mathrm{Fe}^{2+}, \mathrm{Cu}^{2+}\right)$ results in an explosive increase of free radicals and consecutive chain reactions. The presence of chelating agents inhibits the metal catalysis. Controls, which contained no chelating agents, had an absorbance ratio at $485 \mathrm{vs} 530 \mathrm{~nm}$ of $3.55 \pm 0.05$.
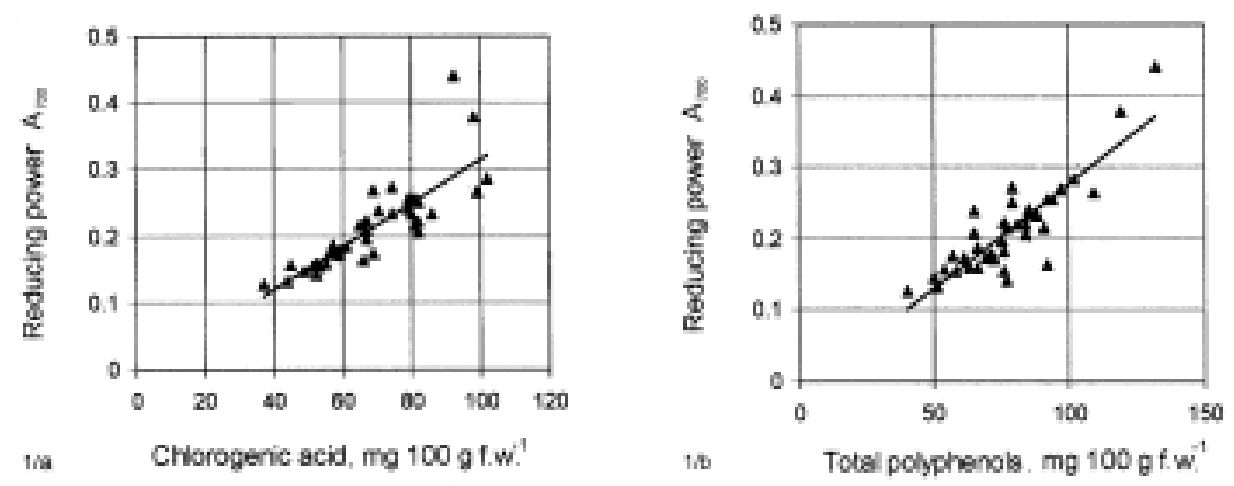

Fig. 1. Linear correlations between the chlorogenic acid content and reducing power (1/a) and total polyphenol content and reducing power $(1 / \mathrm{b})$ of potato tubers. $1 / \mathrm{a}$ : $\mathrm{y}=0.0033 \mathrm{x}-0.0124, \mathrm{R}=0.817$; $1 / \mathrm{b}: \mathrm{y}=0.0029 \mathrm{x}-0.0157, \mathrm{R}=0.859$ 
Table 3

Copper(II)-chelating ability of the potato extracts

\begin{tabular}{lc}
\hline Sample & $\begin{array}{c}\text { Chelating ability } \\
\left(\mathrm{Abs}_{485} / \mathrm{Abs}_{530}\right)\end{array}$ \\
\hline Control $\left(\mathrm{Cu}^{2+}\right)$ & $3.55 \pm 0.05 \mathrm{a}$ \\
Agria & $2.99 \pm 0.04 \mathrm{~b}$ \\
Kennebec & $3.00 \pm 0.03 \mathrm{~b}$ \\
\hline
\end{tabular}

Values are the mean \pm SE of 20 observation. Values followed by the same letter are identical of the $5 \%$ level as determined by the Fisher LSD test

This ratio decreased significantly with the addition of potato samples. The copper chelating ability of potato tubers from both cultivars was around 3.00 compared with 3.55 of the controls (Table 3), and was not affected by $\mathrm{N}$ fertiliser rates.

Hydrogen peroxide has a weak effect on the initiation of lipid peroxidation. However, its activity as active oxygen species comes from its potential to produce the highly reactive hydroxsyl radical through the Fenton reaction $\left(\mathrm{Fe}^{2+}+\mathrm{H}_{2} \mathrm{O}_{2} \rightarrow\right.$ $\left.\mathrm{Fe}^{3+}+\mathrm{OH}^{-}+\mathrm{OH}\right)$. The hydroxyl radical is an extremely reactive species formed in biological systems and reacts rapidly with most biomolecules such as sugars, amino acids, phospholipids, DNA, and organic acids (HALLIWELl \& GUTTERIDGE, 1984). Hydroxyl radicals are capable of abstracting hydrogen atoms from membrane lipids thus bringing about lipid peroxidation (KITADA et al., 1979). Similar to the chelating ability, the scavenging activity of the potato extracts was not affected by $\mathrm{N}$ application. The ethanolic extracts from potato tubers did not reduce the chemiluminescence intensity of the $\mathrm{H}_{2} \mathrm{O}_{2} / \cdot \mathrm{OH}$-luminol-microperoxidase system under the experimental conditions, although pure chlorogenic acid $(0.2 \mathrm{w} / \mathrm{v} \%$ in methanol, $0.01 \mathrm{ml})$ induced a significant decrease on chemiluminescence (Table 4). Toxic free radicals can be generated from flavonoids and other polyphenols depending on their concentration under special circumstances (GYÖRGY et al., 1992, SINDEN et al., 1988). It is possible that such mechanism could modify the total scavenging characteristic of the potato extracts in our experimental system.

Ethanolic extracts of potato tubers inhibited the autoxidation of the linoleic acid measured by thiocyanate method (Table 5). Total antioxidant activity was significantly correlated with the level of chlorogenic acid $(\mathrm{r}=0.782 ; \mathrm{n}=40)$ and the total polyphenols $(\mathrm{r}=0.686 ; \mathrm{n}=40)$ as it can be seen in Figs $2 / \mathrm{a}$ and $2 / \mathrm{b}$. The water-soluble glycoprotein patatin has been considered a major source of antioxidant activity. AL-SAIKHAN and coworkers (1995) found a $68.7 \%$ inhibition of the autoxidation of $\beta$-carotene/linoleic acid in potato extracts, a much higher activity than that of the other vegetables like onion, 
carrot and bell pepper. In contrast with our results AL-SAIKHAN and co-workers found a poor correlation between antioxidant activity and total polyphenols. Other plant proteins have also been reported to have antioxidant activity (PRATT, 1972). Glutathione, quercetin and ascorbic acid are biologically active compounds found in potato tubers that have shown marked antioxidant activity in different experimental systems (Jones et al., 1992, PRATt \& WATTS, 1964). Epidemiological data also confirm the beneficial health effect of quercetin and other polyphenols (KANDASWAMI \& Middleton, 1997)

Table 4

$\mathrm{H}_{2} \mathrm{O}_{2} / \cdot \mathrm{OH}$ scavenging capacity of the extracts of potato measured by the luminol-dependent chemiluminescence method

\begin{tabular}{lr}
\hline \multicolumn{1}{c}{ Sample } & $\begin{array}{c}\text { Chemiluminescence intensity } \\
\text { (RLU) }\end{array}$ \\
\hline Standard light $\left(\mathrm{H}_{2} \mathrm{O}_{2} / \cdot \mathrm{OH}-\right.$ luminol $)$ & $13,496,605 \pm 403,216 \mathrm{a}$ \\
Agria & $11,309,700 \pm 604,936 \mathrm{a}$ \\
Kennebec & $9,059,518 \pm 1,496,157 \mathrm{a}$ \\
Chlorogenic acid $(0.01 \mathrm{ml}, 0.2 \mathrm{w} / \mathrm{v} \%)$ & $91,681 \pm 1,645 \mathrm{~b}$ \\
\hline
\end{tabular}

Values are means \pm SE of 20 observations per cultivar
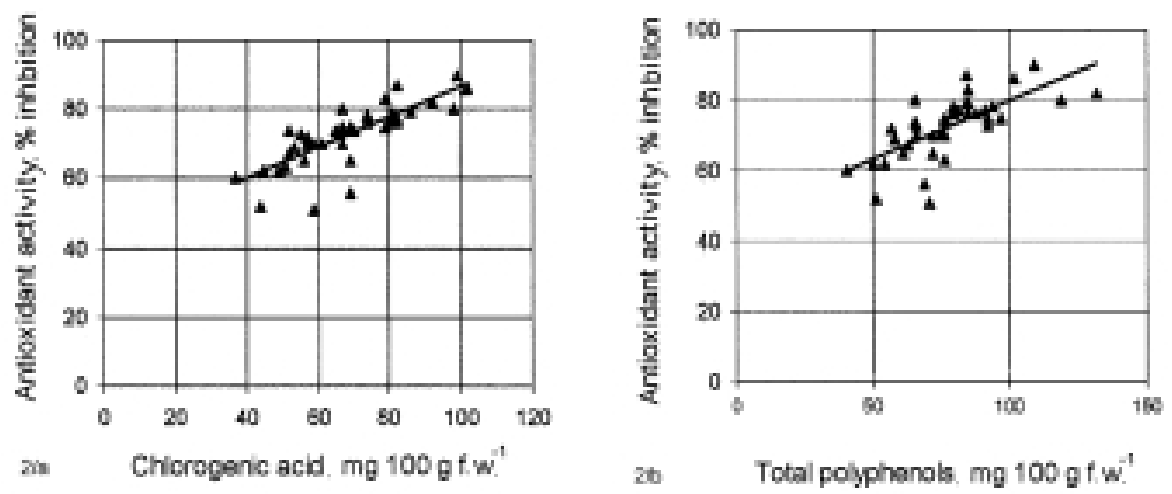

Fig. 2. Linear correlations between the chlorogenic acid content and the antioxidant activity (2/a) and the total polyphenol content and the antioxidant activity $(2 / \mathrm{b})$ of potato tubers. $2 / \mathrm{a}: \mathrm{y}=0.4391 \mathrm{x}+42.356$, $\mathrm{R}=0.781 ; 2 / \mathrm{b}: \mathrm{y}=0.3292 \mathrm{x}+46.89, \mathrm{R}=0.688$ 
Table 5

Antioxidant activity (\% inhibition) of potato tubers grown with several $N$ fertiliser rates

\begin{tabular}{rlc}
\hline $\begin{array}{c}\text { N rate } \\
\left(\mathrm{kg} \mathrm{ha}^{-1}\right)\end{array}$ & Agria & Kennebec \\
\hline 0 & $71.8 \pm 5.7 \mathrm{a}$ & $70.5 \pm 6.8 \mathrm{a}$ \\
75 & $65.5 \pm 4.0 \mathrm{a}$ & $74.0 \pm 1.9 \mathrm{a}$ \\
150 & $70.8 \pm 7.7 \mathrm{a}$ & $70.8 \pm 3.2 \mathrm{a}$ \\
225 & $76.5 \pm 4.6 \mathrm{a}$ & $76.5 \pm 2.3 \mathrm{a}$ \\
300 & $72.3 \pm 4.9 \mathrm{a}$ & $76.8 \pm 0.9 \mathrm{a}$ \\
\hline Average & $71.4 \pm 2.3 \mathrm{a}$ & $73.7 \pm 1.6 \mathrm{a}$ \\
\hline
\end{tabular}

Values are means \pm SE of 4 replications. Mean separation by Fisher LSD test, $5 \%$ level. Mean separation by rows for the $\mathrm{N}$ levels and by columns for the averages over $\mathrm{N}$ levels

\section{Conclusion}

Potato tubers have high concentration of phenolic compounds with chlorogenic acid accounting for up to $90 \%$ of the total. Nitrogen fertiliser rates had minimal or no effect on the concentration of chlorogenic acid, polyphenols, and also on hydrogen donating ability, reducing power, chelating property and antioxidant activity of potato tubers. Ethanolic extracts of the potato tubers proved to be good hydrogen donors and reducing agents. These properties make potatoes good primary and secondary antioxidants, possibly conferring a protective role against the damage caused by free radicals and active oxygen species. Phenolic compounds, mainly chlorogenic acid, are likely to be the major contributors for the reducing power and the antioxidant activity of the tubers. Potato extracts contain copper-binding substances and significantly inhibited the autoxidation of linoleic acid. These properties are probably relevant to the antioxidant activity of potatoes. The overall antioxidant effect of phenolics on lipid peroxidation might be attributed to its properties of scavenging free radicals and active oxygen species. Given the importance of potatoes in the diet they represent a major source of antioxidants. Development of in vitro system to characterise the antioxidant effect of natural plant products merits further investigations.

\section{*}

This work was supported by the National Scientific Research Foundation (F 017713), and by the National Committee of Technical Development, Hungary in collaboration with Junta Nacional de Investigação Científíca e Technologica, Portugal. Authors thank Dr. A. BLÁZOVICS for her help to carry out the luminometric measurements and Mrs. K. TERNÓCZKY-BEDE for her invaluable technical assistance. 


\section{References}

A.O.A.C. (1990): Official Methods of Analysis. 15th ed. Arlington USA 952.03/A-C.

AL-SAIKHAN, M. S. HOWARD, L. R. \& MILLER, J. C. (1995): Antioxidant activity and total phenolics in different genotypes of potato (Solanum tuberosum L.). J. Fd Sci., 60, 341-343.

BLÁZOVICS, A., FEHÉR, E. \& FEHÉR, J. (1992): Role of free radical reactions in experimental hyperlipidemia in the patomechanism of fatty liver--in: CSOMÓS, G. \& FEHÉR, J. (Eds), Free radicals and liver. Springer-Verlag, Berlin, pp. 96-123.

BLOIS, M. S. (1958): Antioxidant determination by the use of a stable free radical. Nature, 4617, 1198-1200.

BYERS, T. \& PERRY, G. (1992): Dietary carotenes, vitamin C, and vitamin E as protective antioxidants in human cancers. Ann. Rev. Nutr., 12, 139-159.

DAO, L. \& FRIEDMAN, M. (1992): Chlorogenic acid content of fresh and processed potatoes determined by ultraviolet spectrophotometry. J. agric. Fd Chem., 40, 2152-2156.

FELICE, L. J., KING, W. P. \& KISSINGER, P. T. (1976): A new liquid chromatography approach to plant phenolics. Application to the determination of chlorogenic acid in sunflower meal. J. agric. $\mathrm{Fd}$ Chem., 24, 380-382.

FRIEDMAN, M., DAO, L. \& GUMBMANN, M. R. (1989): Ergot alkaloid and chlorogenic acid content in different varieties of morning glory (Ipomoea spp.) seeds. J. agric. Fd Chem., 37, 708-712.

FRIEDMAN, M. (1992): Dietary impact of food processing. Ann. Rev. Nutr., 12, 119-137.

FRIEDMAN, M. (1996): Food browning and its prevention: an overview. J. agric. Fd Chem., 44, 631-653.

FRIEDMAN, M. (1997): Chemistry, biochemistry, and dietary role of potato polyphenols. A review. J. agric. Fd Chem., 45, 1523-1540.

GYÖRGY, J., ANTUS, S., BLÁZOVICS, A. \& FÖLDIÁK, G. (1992): Substituents effects in the free radical reactions of sylibinin radiation induced oxidation of the flavonoid at neutral pH. Int. J. Radiat. Biol., $61,603-609$.

HALLIWELL, B. \& GUTTERIDGE, M. C. (1984): Oxygen toxicity, oxygen radicals, transition metals and disease. Biochem. J., 219, 1-14.

HATANO, T., KAGAWA, H., YASUHARA, T. \& OKUDA, T. (1988): Two new flavonoids and other constituents in licoryce root: their relative astringency and radical scavenging effects. Chem. pharm. Bull., 36, 2090-2097.

HEIDE, L. \& BÖGL. W. (1986): The identification of irradiated dried food-stuffs by luminescence measurements. Fd Lab. Newslett., 5, 21-23.

HugheS, J. C., AYERS, J. E. \& SwAIN, T. (1962): After cooking blackening in potatoes. J. Sci. Fd Agric., $13,224-236$

JONES, D. P., COATES, R. J., FlaGG, E. W. ElEy, J. W. BlOCK, G., GREENBERG, R. S., GUNTER, E. W. \& JACKSON, B. (1992): Glutathione in foods listed in the National Cancer Intitute's health habits and history food frequency questionnaire. Nutr. Cancer, 17, 57-75.

KANDASWAMI, C. \& MIDDLETON, E. (1997): Flavonoids as antioxidants.-in: SHAHIDI, F. (Ed) Natural antioxidants. Chemistry, health effect and applications. A.O.C.S. Press, Champaign, IL, pp. 174-204.

KARIM, M. S., PERCIVAL, G. C. \& DIXON, G. R. (1977): Comparative composition of aerial and subterranean potato tubers (Solanum tuberosum L.) J. Sci. Fd Agric., 75, 251-257.

KITADA, M., IGARASHI, K., HiROSE, S. \& KITAGAWA, H. (1979): Inhibition by polyamines of lipid peroxide formation in rat liver microsomes. Biochem. Biophys. Res. Commun., 87, 388-394. 
LAZAROV, K. \& WERMAN, M. J. (1996) : Hypocholesterolaemic effect of potato peel as a dietary fiber source. Med. Sci. Res., 24, 581-582.

MARTENS, M. \& BAARDSETH, P. (1987): Sensory quality.-in: WeICHMAN, J. (Ed) Postharvest physiology of vegetables. Dekker, New York, pp. 427-454.

MITSUDA, H., YASUMOTO, K. \& IWAMI, K. (1966): Antioxidative action of indole compounds during the autoxidation of linoleic acid. Eiyoto Shokuryo, 19, 273-300.

MOLNAR-PERL, I. \& FRIEDMAN, M. (1990): Inhibition of food browning by sulphur amino acids. 3. Apples and potatoes. J. agric. Fd Chem., 38, 1652-1656.

MONDY, N. I. \& GOSSELIN, B. (1988): Effect of peeling on total phenols, total glycoalkaloids, discoloration and flavour of cooked potatoes. $J . F d S c i ., 53,756-759$.

ONYENEHO, S. N. \& HETTIARACHCHY, N. S. (1993): Antioxidant activity, fatty acids and phenolic acids composition of potato peels. J. Sci. Fd Agric., 62, 345-350.

OYAIZU, M. (1986): Studies on products of browning reaction: Antioxidative activities of products of browning reaction prepared from glucosamine. Jpn. J. Nutr., 44, 307-315.

PRATT, D. E. (1972): Water soluble antioxidant activity in soybeans. $J . F d$ Sci., 37, 322-323.

PRATT, D. E. (1993): Antioxidants indigenous to foods. Toxicol. Ind. Health, 9, 63-75.

PRATT, D. E. \& WATTS, B. M. (1964): The antioxidant activity of vegetable extracts. I. Flavone aglycones. J. Fd Sci., 29, 27-33.

RODRIGUEZ DE SOTILLO, D., HADLEY, M. \& HOLM, E. T. (1994a): Phenols in aqueous potato peel extract: extraction, identification and degradation. $J . F d$ Sci., 59, 649-651.

RODRIGUEZ DE SOTILlO, D., HADLEY, M. \& HOLM, E. T. (1994b): Potato peel waste: stability and antioxidant activity of a freeze dried extract. $J$. Fd Sci., 59, 1031-1033.

SHIMADA, K., FUJIKAWA, K., YAHARA, K. \& NAKAMURA, T. (1992): Antioxidative properties of xanthan on the autoxidation of soybean oil in cyclodextrin emulsion. J. agric. Fd Chem., 40, 945-948.

SINDEN, S. L., SANFORD, L. L., CANTELO, W. W. \& DEAHL, K. L. (1988): Bioassays of segregating plant. A strategy for studying chemical defenses. J. Chem. Ecol., 14, 1941-1950.

STEVENS, K. L. WILSON, R. E. \& FRIEDMAN, M. (1995): Inactivation of a tetrachloroimide mutagen from simulated processing water. J. agric. Fd Chem., 43, 2424-2427.

THOMAS, P. \& JOSHI, M. R. (1977): Prevention of after-cooking darkening of irradiated potatoes. Potato Res., 20, 77-84.

TSUCHIYA, T., SUZUKI, O. \& IGARASHI, K. (1996): Protective effects of chlorogenic acid on paraquatinduced oxidative stress in rats. Biosci. Biotech. Biochem., 60, 765-768.

VINSON, J. A., JAN, J., DABBAGH, Y. A., SERRY, M. M. \& CAI, S. (1995): Plant polyphenols exhibit lipoprotein-bound antioxidant activity using an in vitro oxidation model for heart disease. J. agric. Fd Chem., 43, 2798-2799. 